\title{
С.Д. Юрчевский
}

\section{НЕКОТОРЫЕ ПРОБЛЕМЫ ПРОТИВОДЕЙСТВИЯ ПОЛИТИЧЕСКОМУ ЭКСТРЕМИЗМУ (РЕГИОНАЛЬНЫЙ АСПЕКТ)}

$\Pi$

роблемы противодействия экстремизму уже не первый год находятся в центре пристального плексная правовая база - принят Федеральный за- кон от 25 июля 2002 г. № 114-Ф3 «О противодействии экстремистской деятельности» ${ }^{\prime}$; внесены изменения в

1 См.: СЗ РФ. - 2002. - № 30. - Ст. 3031. 
УК РФ и КоАП РФ; высшая судебная инстанция обобщила практику применения антиэкстремистских уголовно-правовых норм и изложила рекомендации по их квалификации ${ }^{2}$ и т.д. Принимаются и меры организационного характера - в структуре правоохранительных органов созданы специальные подразделения, деятельность которых ориентирована именно на противодействие экстремизму.

Однако ситуация в данной сфере остается сложной, причем в разных регионах. Официальные оценки оптимистичными не выглядят: в Стратегии национальной безопасности РФ до 2020 г. $^{3}$ прогнозируется, что в будущем получат развитие националистические настроения, ксенофобия, сепаратизм и насильственный экстремизм, в том числе под лозунгами религиозного радикализма.

Bce это возлагает на государство дополнительные обязанности принятия необходимых мер по предупреждению, пресечению экстремистских деяний, а также по привлечению виновных лиц к юридической ответственности. В силу значительной общественной опасности экстремизма речь должна идти, как правило, об ответственности уголовной. Именно законодательные запреты, в том числе уголовные, являются тем нормативным индикатором, который позволяет формировать в обществе негативное отношение к экстремизму как к не только опасной, но и противоправной деятельности. Прав в этом отношении А.Г. Хлебушкин, указывающий, что в правовом смысле вне конкретных запретов понять суть экстремизма невозможно - он определен именно в них и иначе его нельзя вычленить из всего многообразия форм отклоняющегося поведения; экстремизм в правовом аспекте представляет собой комплекс нормативных запретов, что характерно и для иных видов общественно опасной деятельности. Наиболее опасным же его видом является преступный экстремизм, под которым следует понимать комплекс деяний, из числа альтернативно указанных в ст. 1 Закона «О противодействии экстремистской деятельности», за осуществление которых установлена уголовная ответственность ${ }^{4}$.

«Ядро» преступного экстремизма, в том числе политического - составляют деяния, предусмотрен-

\footnotetext{
2 См.: постановление Пленума Верховного Суда РФ от 28 июня 2011 г. № 11 «О судебной практике по уголовным делам о преступлениях экстремистской направленности» // Российская газета. $-2011 .-4$ июля.

3 Утверждена Указом президента РФ от 12 мая 2009 г. № 537 // С3 РФ. - 2009. - № 20. - Ст. 2444.

4 См.: Хлебушкин А.Г. Экстремизм: уголовно-правовой и уголовно-политический анализ. - Саратов, 2007. - С. 30.
}

ные ст. 280 УК РФ «Публичные призывы к осуществлению экстремистской деятельности»; ст. 282 УК РФ «Возбуждение ненависти либо вражды, а равно унижение человеческого достоинства»; ст. 282.1 УК РФ «Организация экстремистского сообщества»; ст. 282.2 УК РФ «Организация деятельности экстремистской организации».

Особую опасность представляет преступный политический экстремизм, поскольку для его приверженцев характерно стремление к дестабилизации, уничтожению существующих государственных структур, разрушению политической системы современного общества с целью установления нового политического порядка ${ }^{5}$. В связи с антигосударственной направленностью такого экстремизма, к его уголовно-правовой характеристике наряду с приведенными выше нормами УК РФ, можно также отнести деяния, предусмотренные ст. 277 УК РФ «Посягательство на жизнь государственного или общественного деятеля», ст. 278 УК РФ «Насильственный захват власти или насильственное удержание власти» и ст. 279 УК РФ «Вооруженный мятеж».

Кроме этого, в УК РФ сформирован институт преступлений экстремистской направленности, под которыми, согласно примечанию к ст. 282.1 УК РФ понимаются преступления, совершенные по мотивам политической, идеологической, расовой, национальной или религиозной ненависти или вражды либо по мотивам ненависти или вражды в отношении какой-либо социальной группы, предусмотренные соответствующими статьями Особенной части УК РФ и п. «е» ч. 1 ст. 63 УК РФ.

Все это позволяет сделать вывод о том, что в целом уже существует необходимая нормативно-правовая база, позволяющая адекватно реагировать на проявления политического экстремизма.

Вместе с тем, согласно ст. 2 Закона «О противодействии экстремистской деятельности» одним из принципов такого противодействия назван приоритет мер, направленных на предупреждение экстремистской деятельности. Для выработки эффективных мер предупреждения политического экстремизма на $\mathrm{Ce}$ верном Кавказе необходимо, прежде всего, понять суть данного явления.

Как отмечает О.И. Аршба, в политическом плане экстремизм отрицает существующие легитимные и социальные структуры и институты, стремится к разрушению стабильности в обществе, пропагандирует авторитарную политическую систему, представляющую собой единый сплав государства этнически,

\footnotetext{
5 См.: Афанасьев Н.Н. Идеология терроризма // Социально-гуманитарные знания. - 2002. - № 1. - С. 230.
} 
расово и конфессионально гомогенного народа. Господство тотальной идеологии, отражающей систему взглядов экстремистов, искоренение всякого инакомыслия представляются им идеальным порядком в обществе ${ }^{6}$.

В.С. Ковалев дает следующее определение политического экстремизма - это совокупности идей и методов целенаправленной политической деятельности индивидуумов, организованных групп, политических и общественных организаций, движений, общественнополитических блоков и других субъектов политической деятельности, предусматривающих и допускающих применение нелегитимного насилия (или публичных призывов к применению насилия) во всех его разновидностях по отношению к политическим оппонентам, к существующему политическому режимуㄱ.

К политическому экстремизму должна быть отнесена, прежде всего, деятельность по распространению таких идей, течений доктрин, которые направлены на пропаганду и, в конечном счете, на установление тоталитарного строя, для которого свойственны: произвол и насилие; ликвидация возможности свободного распространения и обмена идеями; разделение людей по классовому, имущественному, расовому, национальному или религиозному признакам; невозможность самому обществу легально трансформировать режим. Основная же опасность политического экстремизма заключается в его способности негативно воздействовать на всю общественно-политическую жизнь, разрушать государственные устои, чему способствуют следующие факторы: существенно снижается уровень дозволенного в политике, вследствие чего приоритетными становятся методы конфронтационные, а не консолидирующие; в обществе распространяется нетерпимость, снижается уровень стабильности в обществе; насилие все более воспринимается как допустимый и даже наиболее предпочтительный метод достижения целей; доминирующим мотивом гражданской жизни становится страх, а это - лучший фон для прихода экстремистов к власти ${ }^{8}$.

Вместе с тем, применительно к Северному Кавказу вряд ли можно говорить о политическом экстремизме в чистом виде. Для данного региона характерен, скорее, комплексный вид экстремизма. Так, в теории выделя-

6 См.: Аршба О.И. Современный правый экстремизм в Европе // Вестник Московского университета. Сер. Социология и политология. -2002 . - № 4. - С. 4

7 См.: Ковалев В.С. Политический экстремизм и механизм противодействия ему в современной России: Автореф. дис. ... канд. полит. наук. - М., 2003. - С. 16.

8 См.: Краснов М. Политический экстремизм - угроза государственности // Российская юстиция. - 1999. - № 4. - С. 4. ют религиозно-политический вид экстремизма - это религиозно мотивированная или религиозно камуфлированная деятельность частных или должностных лиц, а также общественных объединений, направленная на насильственное изменение государственного строя, или насильственный захват власти, нарушение суверенитета и территориальной целостности государства, на организацию в этих целях незаконных вооруженных формирований и возбуждение религиозной вражды и ненависти 9 . Аналогично, и религиозный экстремизм практически никогда не выступает в «чистом виде». Как правило, истинной причиной религиозных конфликтов выступают экономические и политические интересы ${ }^{10}$.

Также можно выделить социально-политический вид экстремизма - общественно-политическое явление, сущность которого состоит в радикальном характере деятельности субъектов социально-политических отношений, основанном на приверженности к крайним оценкам условий, в которых эта деятельность происходит. Его идеологической основой является отрицание проводимого курса реформ и стремление утвердить свою систему взглядов и навязать ее оппонентам. Средствами достижения цели социально-политического экстремизма являются словесно выраженные крайности суждений, безапелляционность, категоричность, что в практической деятельности неизбежно приводит к насилию ${ }^{11}$. В целом же, политическая сущность экстремизма детерминирует многогранную его природу, что, в свою очередь, объясняет возможность сочетания политического экстремизма с другими его видами.

Наиболее полной представляется характеристика политического экстремизма, предложенная С.Н. Фридинским, который приводит следующие его признаки:

1. Политическая направленность экстремистской деятельности, осуществление ее в целях борьбы за власть. Политический характер целей указывает, что, не отличаясь от других подсистем политической борьбы постановкой основной цели - прихода к власти, политический экстремизм расходится с ними по способам ее достижения. Если его политические противники стремятся прийти к власти легитимным путем, то политический экс-

\footnotetext{
9 См.: Нуруллаев А.А. Преодоление религиозного политического экстремизма - важное условие укрепления национальной безопасности России // Безопасность Евразии. 2002. - № 1. - C. 544 .

10 См.: Василенко В.И. Исламский экстремизм в Северо-Кавказском регионе // Безопасность Евразии. - 2002. - № 1. - С. 539.

11 См.: Воронов И.В. Основы политико-правового ограничения социально-политического экстремизма как угрозы национальной безопасности Российской Федерации: Автореф. дис. ... канд. полит. наук. - М., 2003. - С. 13.
} 
тремизм пытается ее захватить, используя свой основной метод, т.е. насилие.

2. Использование насилия или угрозы его применения по отношению к объектам своих политических интересов путем агрессивного физического и морально-психологического воздействия, стремление добиться поставленных целей любыми средствами.

3. Организованный характер деятельности, наличие системы различных по своей структуре, идейнополитической направленности и материальнотехнической обеспеченности политических образований, составляющих субъект политического экстремизма.

4. Отказ субъектов политического экстремизма от компромиссов, принятия договоренностей с политическими противниками, что объясняется, во-первых, решительностью в достижении поставленных целей, во-вторых, использованием насилия в качестве основного метода в своей стратегии, и, в-третьих, отсутствием веры в возможность достижения политических целей иными путями ${ }^{12}$. С учетом изложенного можно привести следующие меры по предупреждению политического экстремизма на Северном Кавказе:

1. В науке отмечается, что отдельные религии иногда используются как инструмент борьбы, политический фактор ${ }^{13}$. Исходя из этого, а также с учетом крайней опасности дальнейшего распространения в России экстремизма, обусловленного, прежде всего, национальными и конфессиональными факторами, органы государственной власти РФ, правоохранительные органы должны вести целенаправленную борьбу с антиконституционной деятельностью экстремистских организаций, в том числе, связанных с нетрадиционным исламом, особенно на территории Южного Федерального округа ${ }^{14}$.

2. При противодействии экстремизму весьма важным направлением деятельности представляется борьба с агитацией экстремистов. Данное направление условно предлагается разделять на: а) нейтрализа-

12 См.: Фридинский С.Н. Противодействие экстремистской деятельности (экстремизму) в России (социально-правовое и криминологическое исследование): Автореф. дис. ... д-ра юрид. наук. - М., 2011. - С. 16.

13 См.: Фокин М.С. Уголовно-правовая характеристика организации религиозных объединений, посягающих на личность и права граждан: Автореф. дис. ... канд. юрид. наук. Омск, 2000. - С. 3.

14 См.: Фридинский С.Н. Борьба с экстремизмом: уголовно-правовой и криминологический аспекты: Дис. ... канд. юрид. наук. - Ростов н/Д., 2003. - С. 160. цию самих агитаторов: вербовка, дискредитация и т.д.; б) нейтрализацию средств агитации, которая должна включать в себя оперативные мероприятия по выявлению подпольных типографий, каналов поставки литературы, а также меры социального противодействия, как то: коллективные работы по уборке наглядных средств агитации экстремистов с улиц города, конкретное (материальное, моральное) поощрение наиболее активных граждан осуществляющих общественную деятельность по противодействию экстремизму и т.д. ${ }^{15}$

3. Представляется необходимой организация комплексной антиэкстремистской пропаганды, как на федеральном, так и региональных уровнях, направленной на формирование адекватного, объективного общественного мнения о сущности экстремизма и методах противодействия ему.

В связи с тем, что экстремисты часто для осуществления своей противоправной деятельности используют сеть «Интернет», необходима разработка соответствующей комплексной системы контроля за электронными средствами массовой информации, принятие мер по своевременному пресечению работы экстремистских сайтов. Так, 26 декабря 2011 г. Нальчикский городской суд признал экстремистским сайт «www.djamaattakbir. com». Инициатором судебного разбирательства выступила прокуратура Кабардино-Балкарской Республики, указавшая на связь ресурса с подразделением международной организации «Имарат-Кавказ», которая в феврале 2010 г. была запрещена в России ${ }^{16}$.

Необходима эффективная реализация на федеральном и региональном уровнях различных программ занятости молодежи, также мер по профилактике экстремизма в этой среде. 7 апреля 2011 г. Министерство спорта, туризма и молодежной политики РФ представило документ, подготовленный совместно с ФСБ и МВД - «Методические рекомендации по профилактике и противодействию экстремизму в молодежной среде». В них, в частности, отмечается, что под влиянием социальных, политических, экономических и иных факторов в молодежной среде, наиболее подверженных деструктивному влиянию, легче формируются радикальные взгляды и убеждения. Таким образом, молодые граждане пополняют ряды экстремистских и террористических организаций, которые активно используют российскую молодежь в своих политических

15 См.: Узденов Р.М. Экстремизм: криминологические и уголовно-правовые проблемы противодействия: Дис. ... канд. юрид. наук. - М., 2008. - С. 161.

16 См.: http://www.sova-center.ru/religion/news/extremism/ counter-extremism/2011/12/d23359/ 
интересах. Поэтому к основным направлениям функционирования системы профилактики экстремистской активности в молодежной среде отнесены: а) нормативно-правовое обеспечение системы профилактики экстремизма в молодежной среде; б) научно-методическое и аналитическое обеспечение профилактики экстремизма в молодежной среде; в) создание системы альтернативных полей, площадок для реализации потенциала молодежи и включения ее в социально одобряемые виды деятельности.
Разумеется, это лишь малая часть мер, которые могут обеспечить достойную защиту общества от угроз экстремистского характера. И приведенные направления выделены лишь в силу своей приоритетности. Однако противодействие экстремизму - не только государственная задача. Полагаем, на гражданском обществе лежит не меньше ответственности за формирование надлежащих общественных отношений, характеризующихся стабильностью и отсутствием социальных конфликтов в условиях многонациональности народа РФ.

\section{Библиографический список:}

1. Афанасьев Н.Н. Идеология терроризма // Социально-гуманитарные знания. — 2002. — № 1 .

2. Аршба О.И. Современный правый экстремизм в Европе // Вестник Московского университета. Сер. Социология и политология. — 2002. — № 4.

3. Василенко В.И. Исламский экстремизм в Северо-Кавказском регионе // Безопасность Евразии. — 2002. — № 1.

4. Воронов И.В. Основы политико-правового ограничения социально-политического экстремизма как угрозы национальной безопасности Российской Федерации: Автореф. дис. ... канд. полит. наук. — М., 2003.

5. Краснов М. Политический экстремизм - угроза государственности // Российская юстиция. — 1999. — № 4.

6. Ковалев В.С. Политический экстремизм и механизм противодействия ему в современной России: Автореф. дис. ... канд. полит. наук. - М., 2003.

7. Нуруллаев А.А. Преодоление религиозного политического экстремизма - важное условие укрепления национальной безопасности России // Безопасность Евразии. — 2002. — № 1.

8. Фридинский С.Н. Противодействие экстремистской деятельности (экстремизму) в России (социально-правовое и криминологическое исследование): Автореф. дис. ... д-ра юрид. наук. — М., 2011. —

9. Фокин М.С. Уголовно-правовая характеристика организации религиозных объединений, посягающих на личность и права граждан: Автореф. дис. ... канд. юрид. наук. — Омск, 2000.

10. Хлебушкин А.Г. Экстремизм: уголовно-правовой и уголовно-политический анализ. - Саратов, 2007.

11. Узденов Р.М. Экстремизм: криминологические и уголовно-правовые проблемы противодействия: Дис. ... канд. юрид. наук. — М., 2008.

\section{References (transliteration):}

1. Afanas'ev N.N. Ideologiya terrorizma // Sotsial'no-gumanitarnye znaniya. — 2002. — № 1.

2. Arshba O.I. Sovremennyy pravyy ekstremizm v Evrope // Vestnik Moskovskogo universiteta. Ser. Sotsiologiya i politologiya. - 2002. - № 4 .

3. Vasilenko V. I. Islamskiy ekstremizm v Severo-Kavkazskom regione // Bezopasnost’ Evrazii. — 2002. — № 1.

4. Voronov I.V. Osnovy politiko-pravovogo ogranicheniya sotsial'no-politicheskogo ekstremizma kak ugrozy natsional'noy bezopasnosti Rossiyskoy Federatsii: Avtoref. dis. ... kand. polit. nauk. — M., 2003.

5. Krasnov M. Politicheskiy ekstremizm — ugroza gosudarstvennosti // Rossiyskaya yustitsiya. — 1999. — № 4.

6. Kovalev V.S. Politicheskiy ekstremizm i mekhanizm protivodeystviya emu v sovremennoy Rossii: Avtoref. dis. ... kand. polit. nauk. - M., 2003.

7. Nurullaev A.A. Preodolenie religioznogo politicheskogo ekstremizma — vazhnoe uslovie ukrepleniya natsional'noy bezopasnosti Rossii // Bezopasnost’ Evrazii. — 2002. — № 1.

8. Fridinskiy S.N. Protivodeystvie ekstremistskoy deyatel'nosti (ekstremizmu) v Rossii (sotsial'no-pravovoe i kriminologicheskoe issledovanie): Avtoref. dis. ... d-ra yurid. nauk. — M., 2011.

9. Fokin M.S. Ugolovno-pravovaya kharakteristika organizatsii religioznykh ob'edineniy, posyagayushchikh na lichnost' i prava grazhdan: Avtoref. dis. ... kand. yurid. nauk. — Omsk, 2000.

10. Khlebushkin A.G. Ekstremizm: ugolovno-pravovoy i ugolovno-politicheskiy analiz. — Saratov, 2007.

11. Uzdenov R.M. Ekstremizm: kriminologicheskie i ugolovno-pravovye problemy protivodeystviya: Dis. ... kand. yurid. nauk. - M., 2008. 